\title{
Teacher-centered or Student-centered Learning Approach to Promote Learning?
}

\author{
Ive Emaliana \\ Faculty of Cultural Study, Universitas Brawijawa Malang \\ ive@ub.ac.id
}

Diterima: 04 April 2017

Direview: 13 Juli 2017

Diterbitkan: 30 November 2017

Hak Cipta @ 2017 oleh Penulis (dkk) dan Jurnal Sosial Humaniora (JSH)

*This work is licensed under the Creative

Commons Attribution International License (CC BY

4.0).

http://creativecommons.org/licenses/by/4.0/ Open Access
Subject Areas: Education, Culture, Language

\begin{abstract}
This study investigates English department students learning needs including their attitudes towards student-centered and traditional teaching approaches, culture learning in English as Foreign Language (EFL) program, attitudes towards authority in class, the main problems encountered in the course in learning English and their practice of language learning strategies. In this empirical study, following Xiao's (2006) questionnaire, the data are collected from undergraduates and postgraduates students. In analyzing the groups, one-way ANOVA Test is used to identify whether the mean score on a variable differed significantly from one group to another by taking into account variation within groups as well as between groups. The findings of this research provide EFL teachers with insightful information on students learning needs as an input to syllabus and material planning, to lesson planning and classroom instruction practice. The study demonstrates the importance of a good understanding of students' variables in TEFL programs at university level in Indonesia.
\end{abstract}

Keywords: learning needs; learning strategies, learner variables

\section{Introduction}

To enable students to succeed in learning English as Foreign Language (EFL), language teaching and learning has witnessed a number of paradigm shifts in the areas of teaching methodology and pedagogic aims. In response to sustainable development of education for appropriate English language learning, many Asian countries, including Indonesia have implemented some approaches in teaching and learning English, include Grammar Translation Method, Direct method, Natural approach, communicative approach, computer assisted language learning (Al Rawi, 2013; Mulongo, 2013; Kamai, 2011; Meng, 2009; Kusumoto, 2008). At present, the main foci of English language teaching in Indonesia is no longer teacher-centered, but student-centered teaching approach (Indrianti, 2012; Lestari \& Widjajakusumah, 2009) that gives students opportunities to improve their analytical skills, problem solving skills, as well as skills in deep learning, lifelong learning, self-directed learning, reflective learning, and motivation. This is aimed to achieve the learning outcomes that satisfy all the objectives of the learning process. As this has been employed, factors which may influence the implementation are identified (Lestari \& Widjajakusumah, 2009). Besides, some studies have been done related to the application of studentcentered approach in the teaching of English in 
Indonesia to some level of education (Indrianti, 2012; Kidwell \& Triyoko, 2012).

However, the implementation of studentscentered in English language teaching at tertiary level needs to be seen whether there is a necessary to modify and update the classroom instructional practice. Research suggests that, it can be done by reducing any gap between students and teacher beliefs through learning need analysis. Xiao (2006: 75) states that preferences, attitude towards studentcentered approach, authority in class, culture learning in EFL program, students' motivation, and main problems encountered in the course of learning English and practice of language learning strategies can give insightful information on learners' learning needs.

Related to this, this study is aimed to investigate the learning needs analysis on learning English that will be used as an input to syllabus and material planning, to lesson planning and classroom instruction practice so that objectives and programs offered to learning English can be modified or improved. Even though the actual needs of English language teaching are various across the country, the applied process of questionnaire design, validation, and data analysis can serve as a model for other institutions in Indonesia or in other parts of the world.

\section{Teacher-centered Learning}

In teacher-centered learning, teachers play important roles in the learning process. Teachers are information providers or evaluator to monitor students to get the right answers, yet students are viewed as learners who passively receive information. In the teaching of EFL, the main focus is getting the students to perform well on state- mandated tests rather than catering to students' need (Zohrabi, et al., 2012). The teachers have less motivation for innovation in teaching. According to Acat \& Dönmez (2009), in teacher-centered learning, teachers usually use particular textbooks, which are mostly grammar oriented and to compare the language structures of native and target languages. In this situation students tend to be more competitive and individualistic because they have less opportunity to think aloud or interact.

As teachers become the most dominant source of information, in teacher-centered learning, for example, all questions which are raised by students, if any, are answered directly by teachers without students' involvement. In designing the class activities, teachers control every single learning experience. Several advantages of having teacher-centered learning are it is suitable for large classes, it takes shorter time to do the class activities, learning materials can be well prepared, teachers may feel less nervous, embarrassed or tongue-tied, teachers can manage the students to speak more in English because teachers can set the criteria when students want to communicate in the class, they should use English (Nagaraju, 2013). In this way of learning the real important thing os to transfer the knowledge to the learners.

\section{Student-centered Learning}

Student-centered learning becomes a pioneer of development of learning approach. In this approach, students activities are important indicators in learning process and quality of learning product (Zohrabi, et al., 2012). In the teaching and learning English, this approach links with flexible learning, experiential learning, and self-directed learning (Acat \& Dönmez, 2009). Therefore, a student- 
centered classroom is a place where teachers consider the needs of the students, as a group and as individuals, and encourage them to participate in the learning process all the time. The teachers' roles are more that of facilitators than instructors. The students are active participants in the learning process, and teachers help to guide the students, manage their activities, and direct their learning.

There are several activities in the learning process that bring many advantages in the learning process in English classes. In student-centered class, students may work alone, in pairs, or in groups (Zohrabi, et al., 2012). When students are working alone, they can prepare ideas or make notes before class discussions, doing listening tasks, do short written assignments, or doing grammar or vocabulary exercises. Students can work together in pairs or groups when they compare and discuss their answers, or read and react to one another's written work and suggesting improvements. Students may work together in discussions or in role-plays, share ideas, opinions, and experiences. According to Nagaraju (2013), these activities bring some advantages to students such as when students are working together in English they talk more, share their ideas, learn from each other, feel more secure and less anxious, and use English in a meaningful way.

\section{Research Method}

This research carried out over five months from August 2016 to December 2016, using quantitative research approach, especially survey study. In this empirical study, the subjects consisted 140 English department students from University of Brawijaya Malang in East Java. The questionnaire data were gathered in the last 20 minutes of the students' class time, via prior agreement with the lecturers. The selection of student informants was completely random with a view to accessing a large number of students from different levels.

The research instruments were Xiao's (2006) questionnaire, consisted 58 items which were written in English and five-point Likert scale was used, and three open-ended questions (See Appendix 1). Prior to be distributed, the questionnaires were tried out to measure its reliability and validity.

The student informants were grouped into three different subgroups based on their university year at undergraduate and graduate level. The purpose of doing this was to identify similarities and differences between the sub-groups and subsequently the causes of the variation can be explored. One-way ANOVA test was used to identify whether the mean scores on a variable differed significantly from one group to another by taking into account variation within groups as well as between groups. The data collected from questionnaire were categorized into 12 inter-related themes. This way of categorization corresponds with Xiao's (2006) learning needs analysis questionnaire.

\section{Findings \& Discussion}

Students' Attitude towards Group Work in Class (Questions 1, 2, 3, 4)

The results showed students' positive attitude in group work in class. The ANOVA test indicated that there were no items that show significant differences among the undergraduate and postgraduate students $(\mathrm{P}>0.05)$, meaning that in English class students liked to participate in group work, committed themselves to achieve common goal with their peers, liked teacher-directed group 
work, and listened to their friends for the English oral presentation.

Students' Attitude towards Speaking out in Class (Questions 5, 6, 7, 9, 57)

On question 5, 6, and 7, the results of the ANOVA test showed significant differences between the undergraduates and post graduate students $(\mathrm{P}<0.001,0.002,0.009)$. The postgraduate students tented to show more favorable attitudes than undergraduates towards speaking out in class in the form of asking and answering questions, keeping the discussion atmosphere friendly and harmonious, and not being 'stand out' in voicing opinion or asking questions. However, undergraduate and postgraduates indicated more negative attitude in preparing what to say in English mentally before speaking and generally they did not like to answer questions in English in class. Meaning that, asking and answering questions bring anxiety to them.

Nature and Strength of Motivation among Students (Questions 10, 12, 13, 14, 15, 16, 17)

The findings indicated that the students liked to learn English and were interested in learning about major English-speaking countries. Their interest focused economic, social, political and technological developments in other countries of the world. The results also showed that students' instrumental motivation to learn English especially which deals with their desire to work or to get better work position were high. Moreover, some of the undergraduates students were eager to pursue higher education through enrolling higher level of education or go abroad for advanced study. This finding indirectly supported students' responses in
Question 47 about having a clear long-term aim of learning English.

Students' Attitudes towards Teacher-centered Teaching Method in Class (Questions 18, 27)

The result showed that $47 \%$

respondents agreed and $53 \%$ (74) respondents disagreed with teacher centered teaching method. The students considered this method was effective in some ways but unhelpful in others. Some reasons revealed from the open-ended question, Question 27 that the effectiveness is caused by teacher's competence, nature of the course taught, and classroom activities. The ANOVA test resulted that there was a significant difference between undergraduate and post graduate students $(\mathrm{P}<0.007)$. Undergraduates students, especially who were in the fourth-semester mentioned that teacher-centered teaching method was less effective. Meanwhile, the postgraduate students appeared to be more agreeable to this method, for it is assumed that they have smaller class size and more teacher-initiated or directed discussion in class. In short, this result shows that the whole student-groups held a mildly negative attitude to teacher-centered approach.

Students' Attitudes towards Student-centered Teaching Approach (Questions 19, 28)

Different from Question 18, the finding of Question 19 indicated that the whole student-groups held positive attitude to student-centered teaching approach. The result of the ANOVA test shows that the difference between undergraduate and postgraduates is statistically significant $(\mathrm{P}<0.011)$. This result was strengthened by students' answers on Questions 28. Mostly, they admitted that studentcentered teaching approach led them to master the 
materials in conducive atmosphere of learning, dynamic classroom activities, and offered opportunity to do autonomous learning.

Students' Attitudes to Communicative Activities in Class (Questions 21, 22, 25)

The findings of Question 25 showed that students expressed mixed attitudes towards communicative activity especially when teacher stimulate their interest to do analytical thinking ability through thought-provoking questions than display questions. The ANOVA test showed that the results of Question 25 were significantly different between undergraduates and postgraduates $(\mathrm{P}<0.002)$. Unsurprisingly, postgraduate students show more positive attitude than undergraduate ones. The assumption Nonetheless, other communicative activities like discussions on films/video shows, favorite books, and tips on how to be better learner of English sustain whole studentgroups' interests.

Students' Attitudes towards Non-communicative Activities in Class (Question 20, 24, 42)

The findings showed that students had various responses towards non-communicative activities, like in reading class, for many students still think that reading activities played important roles in the teaching and learning English because they can enhance students' vocabulary and grammatical structures, though teacher-centeredness is commonly found as the teaching method. Because of these, undergraduate students appeared to feel comfortable with this traditional teaching method, while postgraduate students intended to have negative attitude. Based on ANOVA test, Question $20(\mathrm{P}<0.000)$ and Question $24(\mathrm{P}<0.028)$ were significantly different. Besides, the finding of Question 42 revealed that whole student-groups held more to the positive attitudes towards explicit learning. However, this finding is opposite with response in Question 19 about student-centered learning approach.

Culture Learning in EFL (Questions 11, 23, 36, 37)

There were no significant different on the whole student-groups in responding this variable. Students' responses indicated that they liked to learn about target culture in English class, including Western people way of life and social custom especially though text materials.

Students' Attitudes towards Compensation Strategies (Questions 29, 31, 32)

The result of Question 31 showed that students often used gestures as communicative strategies than depending on the native language nor using words or phrases that mean the same thing. On Question 29 and Question 32, the result of ANOVA test showed significant difference between the undergraduates and postgraduates $(\mathrm{P}<0.007)$; $(\mathrm{P}<0.024)$. From the mean difference, it can be shown that postgraduates preferred using words or phrases instead of using Indonesian language as another communicative strategy than the undergraduates.

Students' Attitudes towards Social Strategies (Questions 33, 34, 35)

Social strategies used by undergraduates and post graduates showed very highly positive attitudes. The results of the ANOVA test showed no significant difference among the undergraduate and postgraduate student-groups. Most of them have a peer with whom they often practiced oral English on 
a regular basis, and took part in after-class activities in which English was practiced, for example English club, drama group, or newspaper group.

Students' Attitudes towards Authority (Questions 43, $44,45,46,58)$

The findings of Questions 43, 44, 45 and 46 clearly revealed various responses upon teacher authority in the classes as proven by ANOVA test result $\quad(\mathrm{P}<0.008), \quad(\mathrm{P}<0.016), \quad(\mathrm{P}<0.000), \quad$ and $(\mathrm{P}<0.007)$. Undergraduate students of the second semester as well as post graduate students tended to expect teacher than themselves to be responsible for evaluating how much they have learnt English. Different from undergraduate students in the second semester, the rest of student-groups tended to have responsibility in gaining knowledge from themselves rather than seeing teachers as the only source of knowledge, though they admitted that teaching method used by teacher is very important to students' English study. As indicated in the open-ended questions on Question 58, most of the students found that the current teaching methods used by their teachers of English in English class were contenting $72 \%$ (101) of the students agreed on the statement under the reasons that teachers had used student-centered and teacher-centered teaching approaches appropriately based on the courses. Meanwhile, only 38\% (39) students complained about the teacher way of teaching, whether it was too much on student-centered or teacher-centered approach.

Major Difficulties Encountered in Students, Learning Process (Questions 26, 30, 38, 39, 40, 41, $47,48,49,50,51,52,53,54,55,56)$
Dealing with difficulties encountered by students in learning process, the whole studentgroups indicated that teacher had already helped student with materials difficulty by explaining them in Indonesian language. Thus, students had bravery to do speak in English and had low anxiety in making mistakes. This finding could be explained because students usually used new words in sentences to make them remember them. Some problems like the availability of learning sources for instance materials, audio visuals, and textbooks that are compatible with requirements of studentcentered approach, assurance in getting good TOEFL scores, and guarantee of obtaining a good job after graduation from the university exerted heavy pressure on them. Besides that, some other problems like students' learning style, chances to speak in the class, and teaching methods were responded differently by the whole student-groups as shown by the ANOVA test.

\section{Dicussion}

Regarding the findings revealed that the students' positive attitude towards group work in class may derive from the assumption that teachers have highly adopted active learning teaching methodology as the form of implementing studentcentered teaching approach. As confirmed by Molungo (2013: 157)'s research findings, group work can stimulate learning because students are involved in the class activities. This finding indicates that it is vital to use teaching technique that allow student to work in groups.

However, students' shows various attitudes towards speaking out in class. Given their advanced English proficiency and their specialized area of their study, postgraduate students tend to show more 
positive attitudes than the undergraduate ones. However, some anxieties are found among the whole students' groups when they are asked to speak out in class. Based on Juhana (2012: 100), psychological factors like fear of making mistake, shyness, anxiety, lack of confidence, and lack of motivation hinder students from speaking in English class in Indonesia. These factors are commonly caused by their fear of being laughed at by their friends. Thus, the possible solution is the teachers should be more aware of their students' hindrance to speak out in class.

Meanwhile, the implication of findings for the nature and strength of motivation among students is supported by Emaliana (2011:199) that instrumental motivation is the major motivational orientation for the undergraduate students to learn EFL in Indonesia. It means students need English for graduation (certificate and title) and higher studies.

The result of students' attitudes towards teacher-centered teaching method and studentcentered teaching approach in class revealed that both need to be used in combination to suit the Indonesian EFL context. In other words, no 'pure' student-or teacher-centered approach will be effective in the teaching and learning process. Harmer (2011) strengthens that no single teaching method that can possibly 'cure', which means that various teaching methods should be used by teachers to meet all of students' needs.

The findings on students' attitudes to communicative and non-communicative activities in class are various. The implications of these findings are clear; teachers need to make various communicative and non-communicative class activities through interesting teaching media.
Emaliana (2011:199) suggests that teachers need to select teaching media which meet the students' needs. As stated in the research findings, Indonesian students like to listen English songs, watch English movies, and read non-fiction books. Besides, students expressed a strong desire in culture learning in EFL. This finding alerts teachers to the need to develop a pedagogy which can integrate culture into EFL education.

The findings on students' attitudes towards compensation strategies show that communicative strategies are needed to be taught to EFL students, like how to use gestures, words or phrases that mean the same things. The needs to know appropriate communicative strategies will enhance the teaching and learning of English. Besides that, the students' attitudes toward social strategies are highly positive. Therefore, teachers need to encourage and motivate the students to improve their involvement in extracurricular activities or after-class activities to practice their English.

Regarding to the findings on students' attitudes towards authority, students respect teachers based on god quality of teaching performance and thus, teachers become moral examples to students. Teachers also need to select appropriate teaching method that promotes learning, so, they need to be professional. Therefore, teachers' awareness on their professional development is needed to sustain their professionalism. Hartatik (2011: 422) mentions teachers are expected to be active in both in-service training and on-service training programs to improve their competences and professionalism.

Deal with major difficulties encountered in students' learning process, it is obvious that teachers need to concern with their teaching method. Appropriate teaching method that can promote 
learning will solve the problems faced by the students. To select suitable element in determining the success of English language learning, the selection and preparation of teaching materials are important. Materials which tailored to students' need is effective to facilitate better learning and to enhance students' learning experiences (Indrianti, 2012: 380).

\section{Conclusion}

The results of the study do show a tendency that teacher-centered teaching method and studentcentered teaching approach should be implemented in EFL teaching and learning. Not only one of them, but both of them can be used to enhance both effective teaching and learning at different levels. At tertiary level of education, the ideal way to innovate English teaching and to meet learner's needs is by promoting learning. Teachers have to use studentcentered and teacher-centered approaches appropriately based on the materials discussed.

Due to the time constraints and scope of the study, the present study only accesses the learning needs, future research needs to consider the target needs to make a complete need analysis in teaching English in tertiary level of education. The limitations of the present study leave gaps for other researchers to fill in through further investigations. One of suggested future studies is about designing appropriate curriculum to teach EFL using studentcentered and teacher-centered approaches appropriately.

\section{References}

Acat, B. and Dönmez, İ. (2009). To Compare Student Centered Education and Teacher Centered Education in Primary Science and Technology Lesson in Terms of Learning Environments. Procedia Social and
Behavioral Sciences 1.

Al Rawi, Ismail (2013) Teaching Methodology and Its Effects on Quality Learning. Journal of Education and Practice, vol 4, No. 6. Retrieved on 29 June 2013, from http://www.iiste.org/Journals/index.php/JEP /article/view/4820

Emaliana, Ive (2011) A Survey on the Relationship between Motivation and Achievement of English Department Students of State University of Malang. In Cahyani, Hilda. and Cahyono, Bambang Yudi (Eds.), Best Practices in the Teaching of English. Malang: State University of Malang Press.

Harmer, Jeremy (2011) The Practice of English Language Teaching. Longman: New York

Hartatik, Sri Fatmaning (2011) Improving Teachers Professionalism: Toward Better English Language Teaching in Indonesia. In Cahyani, Hilda. and Cahyono, Bambang Yudi (Eds.), Best Practices in the Teaching of English. Malang: State University of Malang Press.

Indrianti (2012) Developing Student-centered Grammar Materials for Beginners' Level Indonesian. Electronic Journal of Foreign Language Teaching 9(1), pp 380-401. Retrieved on 29 June 2013 from eflt.nus.edu.sg/v9s12012/indrianti.pdf

Juhana (2012) Psychological factors that hinder Students from Speaking in English Class (A Case Study in a Senior High School in South Tangerang, Banten, Indonesia). Journal of Education and Practice 3(12): 100-110. Retrieved on 6 March 2013 from http://www.iiste.org/Journals/index.php/JEP /article/viewFile/2887/4905.

Kidwell, Tabitha Julia and Triyoko, Hanung (2012) Implementing a Student-Centered Pedagogy: Doing so in the Indonesian Teaching-Learning Context. Register, 5 (1). Retrieved on 29 June 2013 from http://eprints.stainsalatiga.ac.id/91/

Kamai, Richard (2011) Toward an Integrated Framework for Language Testing and Intervention. Journal of Education and Practice 2 (8),pp. Retrieved on 20 June 2013 from www.iiste.org/Journals/index.php/JEP/articl e/view/654

Kusumoto, Yoko (2008) Need Analysis: Developing a Teacher Training Program for Elementary School Homeroom teachers in Japan. Second Language Studies, 26 (2):1-4, Retrieved on 20 June 2013 from 
www.hawaii.edu/sls/sls/wp-

content/uploads/2011/06/Kusumoto.pdf

Lestari, Endang., Widjajakusumah, Djauhari (2009)

Students' Seflt-directed Learning

Readiness, Perception toward Student-

Centered Learning and Predisposition towards Student-centered Behaviour. South East Asian Journal of Medical Education 3(1). Retrieved on 29 June 2013 from seajme.md.chula.ac.th/articleVol3No1/OR8 Endang\%20Lestari.pdf

Meng, Qingguo (2009) Study on the Case Teaching method and the Sustainable Development Education for the Inner Mongol Colleges. Journal of Sustainable Development 2(1). Retrieved on 29 June 2013 from http://www.ccsenet.org/journal/index.php/js $\mathrm{d} /$ article/view/243

Zohrabi, M., Torabi, M.A., Baybourdiani, P. (2012). Teacher-centered and/or Student-centered Learning: English Language in Iran. English Language and Literature Studies 2(3).

Nagaraju, Ch., Madhavaiah, G. and Peter, S. (2013) Teacher-Centred Learning and StudentCentred Learning in English Classroom: the Teaching Methods Realizing the Dreams of Language Learners. International Journal of Scientific Research and Reviews 2(3), 125131. 
Appendix 1. The Questionnaire Indicators

\section{Students' Attitude towards Group Work in Class}

1. In English class, I like to participate in group work with 2-4 people, e.g. English dialogues, group discussion, role play.

2. In group work, I like committing myself to achieving our common goal with my peers.

3. I like my teacher to divide the whole class into several small groups in which we do teacher-directed group work.

4. In English class, I like listening to my peers give English oral presentations of interesting stories or information that are well-prepared outside of class.

\section{Students' Attitude towards Speaking out in Class}

1. In group work, I like to ask and answer questions in English.

2. When working in a group, I like to help keep the atmosphere friendly and harmonious

3. In group work, I do not like to 'stand out' by voicing my opinions or asking questions

4. In class or in group activities, I like to prepare what I want to say in English mentally before I speak

5. I like to answer questions in English in class.

\section{Nature and Strength of Motivation among Students}

1. I work especially hard when my own success will benefit me and other people (e.g. my family or my relatives)

2. I like learning English

3. I am interested in the cultures of major English-speaking nations

4. I learn English because I want to know about the economic, social, political and technological developments in other countries of the world

5. I learn English because I want to find a good job

6. I want to be enrolled in the Master degree program

7. I want to go abroad for advanced study or work

\section{Students' Attitudes towards Teacher-centered Teaching Method in Class}

1. In English class, I like a teacher-centred teaching method employed by teachers

2. Do you like a teacher-centred teaching method in English class?

Yes No Please state your reasons why you like or do not like it.

\section{Students' Attitudes towards Student-centered Teaching Approach}

1. In English class, I like a student-centred teaching method employed by teachers

2. Do you like a student-centred teaching method in English class?

Yes No Please state your reasons why you like or do not like it.

\section{Students' Attitudes to Communicative Activities in Class}

1. In English class, I like teacher-guided and text-related discussions on such topics as population problems, my favourite books, films, or how to be a better learner of English

2. In English class, I like to watch English language films or videos, and then discuss them in groups with teacher' facilitation and guidance

3. In English class, I like my teacher to ask students text-based and thought-provoking questions to keep the lesson interesting in order that students have chances to practise their spoken English

\section{Students' Attitudes towards Non-communicative Activities in Class}

1. In the English Intensive Reading class, I like my teacher to deal with the text materials in a sentence-bysentence way

2. In English class, I like to do simulation test exercises and listen to my teacher' explanations

3. I link its Indonesian meaning to a new word to help me remember the word in English 


\section{Culture Learning in EFL}

1. In English class, I like to learn about Western cultures including their way of life, social customs, etc.

2. I learn a lot about western cultures from my English classes

3. My knowledge about Western culture(s) mainly comes from English classroom teaching and learning

4. I like to read English language text materials which cover Western cultures

\section{Students' Attitudes towards Compensation Strategies}

1. If I cannot think of a word during a conversation in English, I depend on my native language to explain it

2. When I can't think of a word during a conversation in English, I use gestures

3. When I can't think of a word during a conversation in English, I use a word or phrase that means the same thing

\section{Students' Attitudes towards Social Strategies}

1. I have at least one peer with whom I often practise English

2. I like to participate in extra-curricular activities in which I can practise my oral English, e.g. English corner

3. I like after-class activities in which I can practise my English writing skills, e.g. drama group and newspaper group

\section{Students' Attitudes towards Authority}

1. I expect my teacher rather than myself to be responsible for evaluating how much I have learnt

2. In class I see the teacher as somebody whose authority should not be questioned

3. I see knowledge, as something that the teacher should pass on to me rather than something that I should discover myself

4. In English class, the teaching method used by the teacher is very important to students' English study

5. Are you content with the current teaching methods used by your teachers of English in English class? Please explain.

\section{Major Difficulties Encountered in Students' Learning Process}

1. In English class, I like my teacher to translate some difficult paragraphs of text materials into Indonesian to enhance my comprehension and translation skills

2. I try to relax myself whenever I am feeling afraid of using English, especially oral English

3. I encourage myself to speak English even when I am afraid of making a mistake

4. I give myself a reward or treat when I do well in English. For example, I reward myself by going to a restaurant, etc

5. I remember new words by thinking of relationships between what I already know and new things I learn in English

6. I use new words in a sentence so I can remember them well

7. I do not have a clear long-term aim of learning English, and lack motivation

8. My learning styles are too rigid and inflexible

9. I have few opportunities to practice my English

10. There is a lack of authentic English materials, audio and visual

11. The idea of finding a good job after graduation from the university exerts heavy pressure on me

12. We lack chances to speak English in class

13. Mid-term tests, Final tests of the courses in the department, and TOEFL test exert heavy pressures on me

14. Teachers place too much stress on the structure, grammar and reading comprehension in English class

15. The English language textbooks are not compatible with the requirements of the student-centred approach in English class

16. We have little knowledge or information about Western cultures

\section{Appendix 2. The Mean Value and Standard Deviation of Student}

Questionnaire data $(\mathrm{N}=140)$

\begin{tabular}{|c|c|c|c|c|c|c|c|}
\hline Question 1 & 4.12 & Question & 3.95 & Question & 3.99 & Question & 3.31 \\
& .83 & 15 & .95 & 31 & .86 & 45 & .95 \\
\hline
\end{tabular}




\begin{tabular}{|c|c|c|c|c|c|c|c|}
\hline Question 2 & 3.73 & Question & 4.07 & Question & 4.07 & Question & 4.05 \\
& .69 & 16 & .83 & 32 & .81 & 46 & .97 \\
\hline Question 3 & 3.75 & Question & 4.25 & Question & 3.59 & Question & 2.80 \\
& .82 & 17 & .83 & 33 & .89 & 47 & 1.1 \\
\hline Question 4 & 3.82 & Question & 3.24 & Question & 3.45 & Question & 3.04 \\
& .82 & 18 & .98 & 34 & .97 & 48 & .98 \\
\hline Question 5 & 3.67 & Question & 3.67 & Question & 3.45 & Question & 3.12 \\
& .82 & 19 & .78 & 35 & .95 & 49 & 1.00 \\
\hline Question 6 & 4.22 & Question & 3.40 & Question & 3.31 & Question & 3.26 \\
& .86 & 20 & .91 & 36 & .91 & 50 & 1.08 \\
\hline Question 7 & 2.92 & Question & 4.02 & Question & 3.5 & Question & 3.39 \\
& 1.03 & 21 & .79 & 37 & .96 & 51 & .95 \\
\hline Question 8 & 3.69 & Question & 4.22 & Question & 3.80 & Question & 3.15 \\
& .98 & 22 & .82 & 38 & .84 & 52 & 1.11 \\
\hline Question 9 & 4.09 & Question & 3.32 & Question & 3.35 & Question & 3.30 \\
& .86 & 23 & .91 & 39 & 1.04 & 53 & 1.03 \\
\hline Question & 4.18 & Question & 3.75 & Question & 3.93 & Question & 3.06 \\
10 & .85 & 24 & .80 & 40 & .69 & 54 & .96 \\
\hline Question & 3.65 & Question & 3.86 & Question & 3.90 & Question & 3.08 \\
11 & .88 & 25 & .76 & 41 & .85 & 55 & .96 \\
\hline Question & 4.37 & Question & 3.84 & Question & 3.70 & Question & 3.22 \\
12 & .75 & 26 & .91 & 42 & .92 & 56 & .90 \\
\hline Question & 3.82 & Question & 3.70 & Question & 3.52 & Question & 3.53 \\
13 & .89 & 29 & .94 & 43 & .94 & 57 & .90 \\
\hline Question & 3.46 & Question & 4.08 & Question & 3.02 & & \\
14 & 1.08 & 30 & .80 & 44 & .96 & & \\
\hline
\end{tabular}

Appendix 3. Twenty one Items Showing Significant Differences by The One-way ANOVA Test Across three student sub-groups

\begin{tabular}{|l|l|l|c|}
\hline N=210 & Df & F value & $\begin{array}{c}\text { ANOVA } \\
\text { Sig. P }<0.05\end{array}$ \\
\hline Question 5 & 2 & 7.172 & 0.001 \\
\hline Question 6 & 2 & 6.396 & 0.002 \\
\hline Question 7 & 2 & 4.897 & 0.009 \\
\hline Question 18 & 2 & 5.098 & 0.007 \\
\hline Question 19 & 2 & 4.639 & 0.011 \\
\hline Question 24 & 2 & 3.653 & 0.028 \\
\hline Question 20 & 2 & 13.968 & 0.000 \\
\hline Question 25 & 2 & 6.262 & 0.002 \\
\hline Question 29 & 2 & 5.131 & 0.007 \\
\hline Question 32 & 2 & 3.813 & 0.024 \\
\hline Question 38 & 2 & 3.958 & 0.021 \\
\hline Question 40 & 2 & 4.065 & 0.019 \\
\hline Question 43 & 2 & 4.941 & 0.008 \\
\hline Question 44 & 2 & 4.272 & 0.016 \\
\hline Question 45 & 2 & 18.373 & 0.000 \\
\hline Question 46 & 2 & 5.075 & 0.007 \\
\hline Question 47 & 2 & 3.288 & 0.040 \\
\hline Question 48 & 2 & 5.277 & 0.006 \\
\hline Question 49 & 2 & 6.131 & 0.003 \\
\hline Question 52 & 2 & 8.680 & 0.000 \\
\hline Question 54 & 2 & 3.951 & 0.021 \\
\hline
\end{tabular}

